Jurnal Ilmu dan Teknologi Peternakan Indonesia Volume 6 (1) 1 - 9; Juni 2020

p-ISSN: 2460-6669 e- ISSN: 2656-4645

\title{
Profil Peternakan Ayam Ras Petelur dan Analisa Faktor Pemicu Belum Tercapainya Swasembada Telur Konsumsi di Nusa Tenggara Barat
}

\section{(Profile of Laying Chicken Farm and Analysis of Factors Causing West Nusa Tenggara to Not Self-Sufficient in Producing Eggs for Consumption)}

\author{
Mohammad Hasil Tamzil dan Budi Indarsih \\ Laboratorium Produksi Ternak Unggas, Fakultas Peternakan Universitas Mataram, \\ Jl. Majapahit Mataram-Lombok. Nusa Tenggara Barat. 83125 \\ e-mail: emhatamsil@yahoo.com
}

Diterima : 15 Maret 2020/Disetujui : 01 Mei 2020

\begin{abstract}
ABSTRAK
Penelitian ini bertujuan untuk mengetahui profil peternakan ayam ras petelur dalam upaya mengetahui faktor-faktor penyebab Nusa Tenggara Barat belum swasembada telur konsumsi. Pengambilan sampel di pusatkan di pulau Lombok sebagai daerah sentral produksi telur ayam Ras di Nusa Tenggara Barat. Pengambilan sampel peternak dilakukan dengan metode Cluster Stratfied Random Samping, dan dilacak menggunakan metode snow ball. Data yang dikumpulkan terdiri dari jenis dua data, yaitu data primer dan data sekunder. Data primer terdiri data profil peternakan ayam ras petelur dan data jumlah telur yang masuk ke Nusa Tenggara Barat, sedangkan data skunder terdiri dari populasi ayam petelur dan produksi telur di daerah Nusa Tenggara Barat, dan provinsi-provensi tetangga (provinsi se pulau Jawa, Bali dan Nusa Tenggara Timur). Data yang diperoleh dianalisa secara deskriptif komparatif. Hasil penelitian mendapatkan bahwa peternakan ayam petelur di Nusa Tenggara Barat didominasi oleh peternakan kecil dengan skala pemilikan berkisar antara 500 sampai 9000 ekor. Rata-rata peternak sudah mengarah pada penerapan good farming system. Kecilnya populasi peternak dan skala pemilikan ternak menyebabkan Nusa Tenggara Barat mengimport 6.480 ton telur konsumsi per tahun.
\end{abstract}

Kata kunci: profil peternakan, produksi telur, ayam ras petelur, kebutuhan telur konsumsi

\begin{abstract}
The aim of this study is to collect profile of laying chicken farms in West Nusa Tenggara Province to understand factors causing the province to still not self-sufficient in producing egg for consumption purposes. Samples for the study was taken in Lombok Island as the central of laying chicken eggs production in West Nusa Tenggara Province. Samples were taken using Stratfied Random Samling method and were tracked using snow ball method. Data collected consists of primary data and secondary data. Primary data consists of profile of laying chicken farms and number of eggs brought to West Nusa Tenggara. On the other hand, secondary data consists of laying chicken population and number of egg production in the West Nusa Tenggara region and neighboring provinces (provinces in Java, Bali and East Nusa Tenggara). The data obtained were analyzed descriptively. The results showed that laying chicken farms in West Nusa Tenggara were dominated by small scale farms owning from 500 to 9,000 chickens. Most of the farmers tend to practice good farming system. The combination of low number of farmers and chickens population is the reason why West Nusa Tenggara still has to import 6,480 tons of consumption eggs per year.
\end{abstract}

Keywords: farming profile, egg production, laying chicken, demand of consumption egg 


\section{PENDAHULUAN}

Ayam ras ras petelur merupakan jenis unggas yang mempunyai kontribusi terbesar dalam pengadaan telur konsumsi Nasional. Kontribusi ayam petelur sebagai penyedia telur konsumsi menempati urutan pertama dan diikuti oleh ternak itik, ayam kampung dan entok. Data Statistik Nasional mencatat bahwa produksi telur ayam ras pada tahun 2017 adalah 1.527.100 ton, berikutnya ternak itik, ayam buras dan entok masing-masing sebesar 308.600 ton, 210.900 ton dan 35.000 ton (Kementan, 2017).

Ayam ras petelur merupakan unggas eksotik yang sengaja didatangkan dari Negara beriklim dingin ke tanah air untuk mencukupi kebutuhan telur konsumsi nasional. Ayam ras petelur tergolong hewan homeothermic (hewan berdarah panas), dengan ciri-ciri fisiologis suhu tubuh berkisar antara $40,5-41,5^{\circ} \mathrm{C}$, hampir seluruh tubuh ditutupi bulu, tidak memiliki kelenjar keringat, sehingga tidak tahan pada pemeliharaan suhu panas (Etches el al., 2008). Kondisi fisiologis yang seperti itu menyebabkan ternak unggas mengalami kesulitan membuang kelebihan panas tubuh ke lingkungan (Ajakaiye et al., 2010: Zulkifli et al., 2009; Al-Aqil dan Zulkifli, 2009; AlGhamdi, 2008, Al-Fataftah dan AbuDieyeh, 2007; Lin et al., 2005; Cooper \& Washburn, 1998). Ayam ras petelur relatif lebih rentan terhadap serangan stres panas dibandingkan dengan ayam kampung maupun ayam Arab (Tamzil et al., 2013; Tamzil et al. 2014, Tamzil, 2014). Beberapa penelitian mendapatkan bahwa meningkatnya suhu lingkungan akan diikuti oleh peningkatan suhu tubuh (Tamzil et al. 2014, Tamzil, 2014; Tamzil et al., 2015; Tamzil et al., 2016; Tamzil et al., 2018). Hal inilah yang menjadi pemicu munculnya stress panas dan menurunkan pertambahan bobot badan, konsumsi pakan, efesiensi pakan (Mujahid et al., 2005), serta menurunkan produksi telur, bobot telur dan ketebalan kerabang telur (Mashaly et al., 2004).

Dengan demikian berarti bahwa pemeliharaan ayam ras petelur harus dilakukan pada daerah-daerah beriklim sejuk dan kurang cocok dikembangkan pada daerah-daerah dengan suhu dan kelembaban tinggi. Meskipun demikian kondisi wilayah Nusa Tenggara Barat (NTB) yang terdiri dari daerah pegunungan dan dataran rendah, menghadirkan banyak daerah berhawa sejuk terutama di daerah dataran medium dan dataran tinggi.

Dari uraian-uraian terdahulu daerah Nusa Tenggara Barat terutama Pulau Lombok merupakan daerah yang potensial untuk pengembangan ayam ras terutama ayam ras petelur, namun selama ini disinyalir kebutuhan akan telur konsumsi masih belum mencukupi kebutuhan sendiri. Hal inilah yang melatarbelakngi penelitian ini dilaksanakan dengan tujuan mengetahui factor penyebab Nusa Tenggara Barat belum swasembada telur.

\section{METODOLOGI PENELITIAN}

\section{Lokasi Penelitian dan Metode Sampling}

Pengambilan sampel di pusatkan di pulau Lombok sebagai daerah sentral 
produksi telur ayam Ras di Nusa Tenggara Barat. Pengambilan sampel peternak dilakukan dengan metode Cluster Stratfied Random Samping, yaitu sampel diambil di daerah dataran rendah dan medium, yang dilacak menggunakan metode Snow Ball.

\section{Metode Pengumpulan Data}

Data yang dikumpulkan dalam penelitian ini terdiri dari data primer dan data sekunder. Data primer terdiri: 1). Jumlah telur yang masuk ke pulau Lombok. Data jumlah telur yang masuk ke pulau Lombok diperoleh dengan cara dilakukan pengamatan pada arus kendaraan yang membawa telur dari pulau Bali dan atau pulau Jawa di pelabuhan penyebrangan Lembar. 2). Data populasi ayam petelur di daerah Nusa Tenggara Barat, dan provinsi-provensi tetangga NTB, yaitu provinsi se pulau Jawa, Bali dan Nusa Tenggara Timur, diperoleh dengan mengacu pada data yang dikeluarkan oleh Biro Pusat Statistik Pusat tahun 2017.

Data primer merupakan data yang diperoleh di lapangan yang terdiri dari data profil peternakan ayam ras petelur di pulau Lombok. Data ini diperoleh dengan cara melakukan wawancara dengan peternak, dan pengamatan langsung di lokasi usaha dengan menggunakan bantuan daftar pertanyaan (questioner) dan panduan wawancara. Jumlah peternak yang diwawancarai sebagai responden adalah 40 orang $(10 \%$ dari jumlah peternak aktif) berdasarkan informasi dari Asosiasi Peternak Ayam Ras Petelur Pulau Lombok.

\section{Analisis data}

Data profil peternakan yang diperoleh di lapangan dianalisa secara deskriptif, sedangkan untuk mengetahui tingkat kecukupan kebutuhan telur konsumsi, dilakukan analisa komparatif antara jumlah populasi dan produksi telur ayam ras di Nusa Tenggara Barat dan provinsi lain di sekitar Nusa Tenggara Barat. Kemudian dibahas secara deskritif dengan data primer yang diperoleh di lapangan.

\section{HASIL DAN PEMBAHASAN}

Peternakan ayam ras petelur di pulau Lombok dilakoni oleh masyarakat dengan rata-rata umur 41 tahun dan dengan rentang antara 28-56 tahun. Rentangan umur ini tergolong umur produktif dengan latar belakang pendidikan seperti tertera pada Tabel 1 .

Tabel 1. Tingkat pendidikan pelaku bisnis (peternak) ayam petelur di pulau Lombok

\begin{tabular}{llc}
\hline \multicolumn{1}{c}{ Tingkat Pendidikan } & Persen \\
\hline Tidak tamat Sekolah Dasar (TTSD) & - \\
Tamat Sekolah Dasar (SD) & 14 \\
Sekolah Menengah Tingkat Pertama (SMTP) & 14 & \\
Sekolah Menengah Tingakat Atas (SMTA) & 29 & \\
Perguruan Tinggi (PT) & & 43 \\
\hline Terlihat bahwa pelaku bisnis & Lombok tergolong orang-orang \\
beternak ayam ras petelur di pulau & berpendidikan. Pendidikan terbanyak
\end{tabular}


adalah tamat Perguruan Tinggi (Strata 1 dan Diploma 3), kemudian diikuti oleh pendidikan SMTA, serta SMTP dan SD dengan persentase yang sama. Tidak dijumpai adanya peternak yang tidak pernah sekolah maupun tidak tamat sekolah dasar. Hal ini mengandung arti bahwa bisnis budidaya ayam petelur di pulau Lombok ditekuni oleh oleh orangorang terpendidik sehingga sangat memungkinkan pelaku bisnis ini melakukan impropisasi pengembangan kearah yang lebih maju.

Jumlah anggota keluarga peternak berkisar antara 3-7 orang dan dengan rataan 4 orang, serta dengan pengalaman beternak yang sangat variatif. Pengalaman terendah adalah 1 tahun namun ada peternak yang mempunyai pengalaman cukup panjang yang mencapai waktu 30 tahun. Jumlah peternak yang menyatakan diri hidup dari sektor peternak memperlihatkan angka yang paling tinggi (78\%), selebihnya mengaku sebagai guru dan petani (Tabel 2).

Tabel 2. Pekerjaan utama responden

\begin{tabular}{lc}
\hline \multicolumn{1}{c}{ Pekerjaan utama } & Persen \\
\hline Petani & 7 \\
Peternak & 78 \\
Guru & 15 \\
\hline Jumlah & $\mathbf{1 0 0}$ \\
\hline
\end{tabular}

Rata-rata jumlah pemilikan ayam adalah 2401 ekor dengan tingkat pemilikan terendah adalah 500 ekor dan terbanyak adalah 100.000 ekor. Angka pemilikan terbanyak berkisar antara 500 ekor sampai dengan 9.000 ekor. Pemilikan sekala 100.000 ekor hanya dimiliki oleh 2,5\% peternak. Peternak lebih banyak memelihara ayam dari umur dara (pullet) yang dibeli pada peternak yang husus membesarkan DOC dan dijual pada umur dara.

Jenis kandang utama yang dipergunakan oleh peternak ayam ras di pulau Lombok sebagian besar (58\%) beralaskan tanah, berdinding terbuka (92\%) dan dengan atap berbentuk gable (79\%). Didapat juga peternak yang menggunakan lantai kandang dari bahan campuran pasir dan semen (PC) (21\%), dan kandang panggung (21\%). Hanya sebahagian kecil peternak yang menerapkan sistem kandang dengan dinding setengah tertutup (8\%) dan atap sistem monitor (21\%). Tidak diperoleh adanya peternak ayam ras petelur yang menggunakan kandang tertutup (closed house).

Hasil pengamatan langsung di lokasi usaha didapatkan informasi bahwa hampir seluruh responden (86\%) menerapkan arah pembangunan kandang yang benar yaitu memanjang dari timur ke barat, selebihnya membangun kandang membentang dari arah utara selatan. Hal ini mengandung arti bahwa peternak sudah paham tentang mikroclimat kandang dan upaya membuat suasana nyaman di dalam kandang.

Hasil pemantauan suhu mikroclimat dalam kandang diperoleh data rata-rata suhu kandang adalah $28^{\circ} \mathrm{C}$ dengan kisaran 26-30 ${ }^{\circ} \mathrm{C}$. Ternak ayam akan dapat tumbuh dan berproduksi dengan baik bila dipelihara pada suhu $18-23^{\circ} \mathrm{C}$ (Czarick dan Fairchild, 2008), bila suhu meningkat akan memunculkan stress panas dan 
berpengaruh negatif pada produksi telur (Tamzil et al. 2013; Tamzil, 2014).

Dari hasil pengamatan langsung di lokasi usaha diperoleh informasi bahwa ternak ayam dipelihara dalam kandang batre dengan bahan dan ukuran yang variatif. Bahan kandang batre umumnya dibuat dari kawat atau bilah bambu. Bahan pakan menggunakan pakan konsentrat yang dicampur jagung dan dedak dengan perbandingan yang cukup variatif. Perbandingan konsentrat, jagung dan dedak $3: 1: 3$ merupakan aplikasi yang paling banyak diterapkan, berikutnya diikuti oleh perbandingan $2: 1: 2(15 \%)$ kemudian perbandingan $4: 3: 3$ dan $2: 1$ : 1 masing-masing sebanyak (7\%). Pakan diberikan 2 kali sehari pada waktu pagi dan siang hari masing-masing (57\%) dan pada sore hari (43\%) dengan volume disesuaikan dengan panduan yang diterima dari perusahaan tempat membeli pullet. Pola pemberian air minum juga terlihat cukup bervariasi. Sebanyak 57\% peternak memberi air minum 3 kali sehari, yaitu pada pagi, siang dan sore hari, berikutnya sebanyak 35,7\% yang member air minum dengan frekuensi 4 kali sehari, yaitu pagi, siang, sore dan malam hari, sedangkan sisanya yang 7\% memberi air minum pada pagi dan sore hari (2 kali sehari). Air minum umumnya diambil dari air sumur (93\%) dan sisanya diambil dari air Perusahaan Daerah Air Minum (PDAM). Jenis tempat air minum yang dipergunakan juga bervariasi, yaitu dari bahan yang sederhana sampai penggunaan tempat air minum otomatis (nipple). Tidak diperoleh informasi pada masing-masing farm dilakukan tindakan bioskuriti yang ketat. Untuk mencegah munculnya penyakit hanya dilakukan tindakan preventif dengan melakukan program vaksinasi yang dititikberatkan pada vaksinasi ND dab flu burung, jarang yang melakukan vaksinasi yang lain.

Hasil wawancara mendalam dengan peternak didapat informasi bahwa ayam mulai bertelur pada umur yang cukup variatif (Tabel 3).

Tabel 3. Umur mulai bertelur ayam ras pada beberapa farm di pulau Lombok

\begin{tabular}{cc}
\hline Umur (minggu) & Persentase \\
\hline 18 & 29 \\
19 & 7 \\
20 & 43 \\
22 & 14 \\
24 & 7 \\
\hline Jumlah & $\mathbf{1 0 0}$ \\
\hline
\end{tabular}

Terdapat $36 \%$ responden yang mengaku ayamnya mengalami masak kelamin dini (bertelur di bawah umur 20 minggu), dan sebanyak $21 \%$ masuk ke dalam kategori masak kelamin lambat. Persoalan masak kelamin dini ini mungkin disebabkan oleh karena menejemen pemberian pakan pada umur dara yang diberikan secara ad libitum sehingga ternak tumbuh sangat cepat dan menghasilkan masak kelamin dini (Tamzil et al. 1999). Munculnya masak kelamin dini ini merupakan fenomena yang tidak menguntungkan bagi peternak karena akan menghasilkan telur yang kecil dan masa bertelur yang pendek. Munculnya masak kelamin lambat juga memberikan dampak negatif pada peternak, karena untuk menghasilkan seekor petelur membutuhkan pakan yang relatif banyak. 
Hasil wawancara mendalam juga mendapatkan bahwa umur dicapai puncak produksi telur juga bervariasi. Puncak produksi tercepat dicapai pada umur 24 minggu, sementara puncak produksi terlambat dicapai pada umur 30 minggu. Fenomena ini mempunyai hubungan dengan munculnya masak kelamin (bertelur pertama).

Dari uraian terdahulu dapat disimpulkan bahwa peternakan ayam ras petelur di Nusa Tenggara Barat mayoritas tergolong peternak kecil dengan skala pemilikan yang rendah. Rendahnya skala pemilikan ternak ini berdampak pada tingkat populasi ternak di Nusa Tenggara Barat (Tabel 4). Hal ini pula yang menyebabkan produksi telur ayam ras di Nusa Tenggara Barat tergolong paling rendah dibandingkan produksi telur ayam ras di provinsi Bali dan provinsi-provinsi di pulau Jawa (Tabel 4).
Data pada Tabel 4 memperlihatkan bahwa bahwa populsai ayam Ras petelur di Nusa Tenggara Barat hanya mencapai 511.620 ekor dengan kemampuan produksi telur mencapai 22.973 ton. Rendahnya jumlah populasi ayam ras petelur dan rendahnya kemampuan produksi telur di Nusa Tenggara Barat, merupakan peluang besar dikembangkan sebagai daerah penghasil telur. Didukung oleh letak geografis Nusa Ternggara Barat yang sangat dekat dengan provinsi Nusa Tenggara Timur (daerah dengan populasi ayam ras petelur dan produksi telur terendah di kawasan Jawa dan Nusa Tenggara), menjadikan Nusa Tenggara Barat sebagai daerah yang paling strategis sebagai pemasuk telur konsumsi ke wilayah Nusa Tenggara Timur bahkan ke Negara Timor Leste.

Tabel 4. Populasi dan produksi telur di seluruh provinsi di pulau Jawa dan Nusa Tenggara

\begin{tabular}{lcc}
\hline Nama Provinsi & Populasi ayam ras petelur (ekor) & Produksi telur (ton) \\
\hline Daerah Khusus Ibu Kota Jakarta & - & 166 \\
Jawa Barat & 15.475 .462 & 231.067 \\
Jawa Tengah & 22.453 .270 & 303.720 \\
Daerah Istimewa Jogjakarta & 3.692 .806 & 38.246 \\
Jawa Timur & 46.431 .226 & 520.432 \\
Banten & 4.917 .932 & 88.402 \\
Bali & 5.566 .70 & 53.868 \\
Nusa Tenggara Barat & $\mathbf{5 1 1 . 6 2 0}$ & $\mathbf{2 2 . 9 7 3}$ \\
Nusa Tenggara Timur & 203.622 & 7.583 \\
\hline
\end{tabular}

Sumber: Kementan (2017)

Kebutuhan telur konsumsi di Nusa

Tenggara Bartat tidak didapatkan data pasti, meskipun demikian jumlah kebutuhan telur konsumsi dapat diprediksi dengan cara menambahkan jumlah produksi telur di Nusa Tenggara Barat dengan jumla telur yang masuk dari luar daerah. Berdasarkan data statistik tahun 2017 daerah Nusa Tenggara barat hanya mampu menghasilkan 22.973 ton/tahun telur konsumsi, sedangkan jumlah telur yang masuk dari luar daerah rata-rata mencapai 6 truk per hari. Bila setiap truk telur memiliki berat rata-rata 3 ton, maka 
untuk setiap harinya terdapat 18 ton telur yang masuk ke Nusa Tenggara Barat. Berarti dalam satu tahun jumlah telur yang masuk ke Nusa Tenggara Barat adalah 6.480 ton. Berarti jumlah telur yang dibutuhkan di Nusa Tenggara Barat adalah 29.453 ton per tahun. Angka prediksi ini jauh lebih kecil dari prediksi Kepala Dinas Peternakan dan Kesehatan Hewan Nusa Tenggara Barat yang menyatakan daerah Nusa Tenggara Barat membutuhkan tambahan telur sebanyak
22.000.000 butir telur telur konsumsi (setara dengan 1.210 ton per tahun) dari luar Nusa Tenggara Barat (Suara NTB, 2018).

Daerah Nusa Tenggara Barat terutama pulau Lombok banyak memiliki wilayah dataran tinggi dengan kondisi alam yang sejuk (Dradjat et al. 2014), serta merupakan daerah penyedia bahan pakan unggas (Tabel 5).

Tabel 5. Produksi beberapa komoditi pertanian (bahan baku pakan unggas) di pulau Lombok (ton)

\begin{tabular}{lrrrrrrr}
\hline \multirow{2}{*}{ Kabupaten/Kota } & \multicolumn{8}{c}{ Jenis Komoditi } \\
\cline { 2 - 8 } & \multicolumn{1}{c}{$\mathbf{1}$} & $\mathbf{2}$ & $\mathbf{3}$ & $\mathbf{4}$ & $\mathbf{5}$ & $\mathbf{6}$ & $\mathbf{7}$ \\
\hline Lobar & 447277 & 39041 & 2842 & 1878 & 224 & 4587 & 1280 \\
Loteng & 468285 & 13654 & 26332 & 3837 & 526 & 3445 & 4732 \\
Lotim & 941263 & 118630 & 6294 & 968 & 808 & 13277 & 6756 \\
KLU & 941263 & 32130 & 1 & 8631 & 8 & 21799 & 1996 \\
Kota Mataram & 32258 & 13 & 832 & 2 & 1 & - & - \\
Sumbawa & 40348 & 329885 & 9497 & 1446 & 15666 & 13277 & 1835 \\
KSB & 641 & 29597 & 1106 & 123 & 537 & 78 & 328 \\
Dompu & 53072 & 218855 & 35497 & 1826 & 6779 & 40007 & 1298 \\
Bima & 52721 & 170956 & 38382 & 12147 & 2514 & 9200 & 690 \\
Kota Bima & 641 & 7211 & 1876 & 283 & 11 & 3316 & 110 \\
\hline
\end{tabular}

Sumber: NTB Dalam Angka (2018)

Keterangan: $1=$ padi, $2=$ Jagung, $3=$ kedelai, $4=$ kacang tanah, $5=$ kacang hijau, $6=$ ubi kay, $7=$ ubi jalar

Kedua potensi ini menjadikan daerah Nusa Tenggara Barat dapat dikembangkan sebagai lumbung telur, sehingga NTB dapat swasembada telur, bahkan dapat dieksport ke luar daerah terutama ke Nusa Tenggara Timur (NTT) dan ke luar negeri (Timor Leste).

\section{SIMPULAN}

Hasil penelitian menyimpulkan bahwa peternakan ayam ras petelur di Nusa Tenggara Barat didominasi oleh peternakan kecil dengan skala pemilikan berkisar antara 500 sampai 9.000 ekor. Pola produksi sudah mengarah pada penerapan good farming system. Rendahnya jumlah peternak dan skala pemilikan ternak menyebabkan Nusa Tenggara Barat masih belum swasembada telur konsumsi.

\section{DAFTAR PUSTAKA}

Ajakaiye JJ, Ayo JO, Ojo SA. 2010. Effects of heat stress on some blood parameters and egg production of Shica Brown layer chickenss transported by road. Biol Res 43: 183-189. 
Al-Aqil A, and Zulkifli I. 2009. The changes in heat shock protein 70 expression and blood characteristics in transported broiler chickens as affected by housing and early age feed restriction. Poult Sci 88:13581364.

Al-Fataftah AA, Abu-Dieyeh ZHM. 2007. Effect of Chronic Heat Stress on Broiler Performance in Jordan. Int Jour Poult Sci 6 (1): 64-70

Al-Ghamdi ZH. 2008. Effects of commutative heat stress on immunoresponses in broiler chickenss reared in closed system. Int Jour Poult Sci 7(10): 964-968

Cooper MA and Washburn KW. 1998. The relationships of body temperature to weight gain, feed consumption, and feed utilization in broiler under heat stress. Poult Sci 77: 237-242.

Czarick, I. I. I and B.D. Fairchild. 2008. Poultry Housing for Hot Climates. In: N.J. Daghir (Ed.) Poultry Production in Hot Climates. Second Edition.

Dradjat A.S., Hermansyah, M.H. Tamzil, I.P. Sudrana, dan U. Abdullah. 2014. Masterplan Kawasan Peternakan Provinsi Nusa Tenggara Barat. Kerjasama antara Fakultas Peternakan Universitas Mataram dengan Dinas Peternakan dan Kesehatan Hewan Provinsi Nusa Tenggara Barat. Mataram.
Etches RJ. John TM, Verrinder Gibbins AM. 2008. Behavioural, Physiological, Neuroendocrine and Molecular Responses to Heat Stress. In: Nuhad J. Daghir (ed.). Poultry Production in Hot Climates. Trowbridge. Cromwell Press. Pp: 49-69.

Kementan, 2017. Data statistic produksi daging nasional. Kementrian Pertanian, Jakarta, Republik Indonesia.

Lin H, Zhang HF, Du R, Gu XH, Zhang ZY, Buyse J, Decupere E. 2005. Thermoregulation responses of broiler chickens to humidity at different ambient temperatures. II. Four weeks of age. Poult Sci 84:1173-1178.

Mashaly MM, Hendricks GL, Kalama MA, Gehad AE, Abbas AO, Patterson PH. 2004. Effect of heat stress on production parameters and immune responses of commercial laying hens. Poult Sci. 83:889-894.

Mujahid A, Yoshiki Y, Akiba Y, Toyomizu M. 2005. Superoxide radical production in chicken skeletal muscle induced by acute heat stress. Poult Sci. 84:307-314. Mumma JO, Thaxton JP, Vi

NTB Dalam Angka. 2018. Biro Pusat Statistik Provinsi Nusa Tenggara Barat. Mataram.

Suara NTB, 2018. Tiap tahun NTB datangkan 22 juta butir telur dari luar daerah. 
Tamzil MH, Indarsih B and Jaya INS. 2018. Water Spraying Prior to Transportation Reduces Transportation Stress and Maintain the Meat Quality of Broiler Chickens. Pak. J. Nutr., 17 (11): 550-556.

Tamzil, M.H, P.S. Hardjosworo, D.T.H. Sihombing dan W. Manalu, 1999. Pengaruh pembatasan pemberian pakan terhadap penundaan masak kelamin itik Lokal yang cenderung masak kelamin dini. Media Veteriner. 6(2): 5-9.

Tamzil, M.H. 2014. Stres panas pada unggas: Metabolisme, akibat dan upaya penanggulangannya. Wartazoa. (24): 57-67.

Tamzil, M.H., M. Ichsan, N.S. Jaya and M. Taqiuddin. 2015. Growth rate, carcass weight and percentage weight of carcass parts of laying type cockerels, kampong chicken and arabic chicken in different ages. Pakistan Journal of Nutrition. 14 (7): 377-382,

Tamzil, M.H., N.K.D. Haryani and B. Indarsih, 2016. Reduced expression of Heat Shock Protein (HSP) 70 gene by ascorbic acid supplementation in broiler chickens exposed to transportation stress to maintain the quality of meat and hematological parameters. Int. J. Poult. Sci., 15: 432-441.
Tamzil, M.H., R.R. Noor, P.S. Hardjosworo, W. Manalu and C. Sumantri. 2013. Acute heat stress responses of three lines of chickens with different Heat Shock Protein (HSP) 70 genotypes. International Journal of Poultry Science. 12: 264272.

Tamzil, M.H., R.R. Noor, P.S. Hardjosworo, W. Manalu, C. Sumantri. 2014. Hematological Response of Chickens with Different Heat Shock Protein 70 Genotypes to Acute Heat Stress. International Journal of Poultry Science. 13 (1): 14-20.

Zulkifli I, Al Aqil A, Omar AR, Sazili AQ, Rajion A. 2009. Crating and heat stress influence blood parameters and heat shock protein 70 expression in broiler chickens showing short or long tonic immobility reactions. Poult Sci 88:471-476. 